\title{
PREVALENCE OF TOXOPLASMA GONDII IN FINISHING PIGS IN A LARGE-SCALE FARM IN THE CZECH REPUBLIC
}

\author{
E. VOSTALOVÁ ${ }^{1}$, I. LITERÁK ${ }^{1}$, I. PAVLÁSEK ${ }^{2}$, K. SEDLÁK ${ }^{2}$ \\ ${ }^{1}$ Department of Epizootiology, University of Veterinary and Pharmaceutical Sciences, Brno \\ ${ }^{2}$ State Veterinary Institute, Praha \\ Received March 2, 2000 \\ Accepted July 27, 2000
}

Abstract

Vostalová E., I. Literák, I. Pavlásek, K. Sedlák: Prevalence of Toxoplasma gondii in Finishing Pigs in a Large-scale Farm in the Czech. Acta Vet. Brno 1999, 69: 209-212.

In January, April and November 1999, slaughter pigs from a large-scale farm in South Bohemia, Czech Republic, were tested for Toxoplasma gondii antibodies and assayed for T. gondii. The complement fixation test (CFT) revealed antibodies in 4 of 787 pigs $(0.5 \%)$. The Sabin-Feldman test (SFT) of 259 slaughter pigs revealed antibodies in 1 pig $(0.4 \%)$. In the two tests, titres 8 and 4 respectively were considered positive. An isolation biological assay on laboratory mice was used to test tissue specimens from the brain and diaphragm muscles of 97 randomly selected pigs from the April and November tests. The results of the isolation tests were negative. The results showed that between 1981-1990 and 1999, no significant toxoplasmosis seroprevalence changes occurred on this modern large-scale pig farm characterized by a high standard of zoohygiene and veterinary supervision

Pigs, Toxoplasma gondii, antibodies, isolation

Swine toxoplasmosis is a world-wide infection caused by an intracellular parasite, Toxoplasma gondii. In pigs, a latent form of the disease usually develops, but clinical cases of the infection have also been reported (Dubey and B eattie 1988). The real problem of toxoplasmosis in pigs lies in the fact that tissues of infected animals may contain $T$. gondii tissue cysts and these, if ingested in insufficiently cooked pork and if personal hygiene principles were poor when cooking it, may cause latent or even clinical infections in man (Jíra and Rosický 1983). Pig toxoplasmosis has been given particular attention in countries where pork plays an important role in the human diet.

In the Czech Republic, several studies of pig toxoplasmosis have been made in recent decades. The results of serological tests for pig toxoplasmosis from the 1948-1970 period were summarized by Kouba et al. (1974). In that period, seroprevalence among pigs was $37.5 \%, 41.9 \%$ and $10.7 \%$ as ascertained by Sabin-Feldman test (SFT), complement fixation test (CFT) and microprecipitation on agar gel (MPA), respectively. Another study of slaughter pigs was made between 1979 and 1989. In that period, the average seroprevalence in pigs was 8.8\% (Hejlíček and Literák 1993). The most extensive study was made from 1979 to 1990 . It looked into the prevalence of toxoplasmosis among slaughter pigs in the South Bohemian district of Strakonice (Hejlíček and Literák 1993). Antibodies against T. gondii were found in $5.9 \%, 0.3 \%$ and $0.1 \%$ of the animals by SFT, CFT and MPA respectively. The pigs examined came from standard pig farms that offered a possibility for comparison. The results of this study showed a marked decrease in the prevalence of toxoplasmosis among pigs in the 1979-1990 period in comparison with the 1948 - 1970 period. The highest prevalence was found among pigs from small backyard operations, while the prevalence among pigs from traditional large farms - and even more so from modern large-scale farms - were lower.

Address for correspondence:

MVDr. Eva Vostalová

Department of Epizootiology, Faculty of Veterinary Medicine

University of Veterinary and Pharmaceutical Sciences

Phone: +420541562311

Palackého 1-3, 612 42 Brno, Czech Republic 
A trend towards lower seropositivity related to improved zoohygienic conditions in pig farming and more intensive education of farmers has also been observed in the Netherlands (Knapen 1982), Austria (Edelhofer 1994) and the USA (Weigel 1995). The aim of the present study was to compare the T. gondii prevalence on a large-scale pig-rearing farm in 1999 with that in the 1981-1990 period and find what changes, if any, occurred in the prevalence of toxoplasmosis among pigs.

\section{Materials and Methods}

The Animal Production Company farm in Kladruby in the South Bohemian district of Strakonice (Czech Republic) was chosen because that offered an opportunity for a comparison with the results from the 1981-1990. The farm is a modern large-scale pig-rearing facility with 4 halls and a total capacity of 8,600 pigs. There is very good sanitation and constant veterinary supervision at this farm. Commercial feeds are used and cats are prevented from entering the facilities. Although the farm buys piglets from 8 suppliers, most of the piglets come from 2 or 3 of them.

In 1999, a total of 787 blood samples and 97 brain and diaphragm muscle tissue samples were taken in 1999 (January 12, April 20, and November 4) from pigs having the slaughter weight $110 \mathrm{~kg}$ brought to slaughter houses. Randomly selected pigs were serologically examined by the CFT test according to a standard methodology of the Ministry of Health of the Czech Republic with the use of "Sevatest Toxoplasma antigen KFR", "Sevatest Toxoplasma komplement" and "Amboceptor hemologický" (Sevapharma, Praha) and with ovine erythrocytes. In the CFT, the basic dilution was 1:8. The sera were diluted in a twofold series, with titres 8 being considered positive. The specimens from the second (149 specimens) and third (110 specimens) samplings were also SFT tested according to standard methods. The basic dilution was 1:4, the specimens were diluted in a twofold series and titres 4 were considered positive.

Randomly selected 56 and 41 pigs from the second and third samplings respectively were used for an isolation test, in which samples of the brain and diaphragm muscle tissues of the same animal in buffered physiological saline with penicillin $(600,000 \mathrm{IU}$ penicillin $\mathrm{G}$ per $1,000 \mathrm{ml})$ were homogenized in an electrical mixer to a fine suspension. Each sample of $1 \mathrm{ml}$ was then applied intraperitoneally to 2 toxoplasma-negative mice. Five weeks later, the mice were sacrificed, bled and examined for the presence of $T$. gondii tissue cysts (brain squash preparations) and for specific antibodies (indirect fluorescence antibody test, IFAT). For the IFAT, the "Sevatest Toxoplasma antigen NIFR" (Sevapharma) and anti-mouse immunoglobuline SwAM/FITC (Sevapharma) were used. The IFAT basic dilution was 1:20, with titres 20 being considered positive.

For a good comparison of the resultrs in 1999 with the results from the 1981-1990, the methods used in the tests were identical with those used in the studies by Hejlíček and Literák (1993).

\section{Results}

Using the CFT test, antibodies against $T$. gondii were found in 4 of 787 slaughter pigs $(0.5 \%)$. The differences in seroprevalence between different sampling dates were not statistically significant $\left(\chi^{2}\right.$ test, $p>0.05$, Tab. 1$)$. Antibody titres of positive pigs reached 8 $(2 \times), 16(1 \times)$ and $64(1 \times)$.

Using the SFT test, $T$. gondii antibodies were found in 1 of 259 slaughter pigs $(0.4 \%)$ (Tab.1). The antibody titre of the positive pig was 4 . This pig had not antibodies against $T$. gondii in the CFT.

Table 1

The results of the examination of slaughter pigs for toxoplasmosis (pigs from the large-scale farm Kladruby, South Bohemia) (SFT-Sabin-Feldman test, CFT- complement fixation test)

\begin{tabular}{|l|c|c|c|c|c|c|c|c|c|}
\hline \multirow{2}{*}{ Examination date } & \multicolumn{3}{|c|}{ SFT } & \multicolumn{3}{c|}{ CFT } & \multicolumn{3}{c|}{ Isolation experiment } \\
\cline { 2 - 10 } & No. & Pos. & $\%$ Pos. & No. & Pos. & $\%$ Pos. & No. & Pos. & $\%$ Pos. \\
\hline 12 January 1999 & $\mathrm{nt}$ & $\mathrm{nt}$ & $\mathrm{nt}$ & 298 & 3 & 1 & $\mathrm{nt}$ & $\mathrm{nt}$ & $\mathrm{nt}$ \\
20 April 1999 & 149 & 0 & 0 & 252 & 0 & 0 & 56 & 0 & 0 \\
4 November 1999 & 110 & 1 & 0.9 & 237 & 1 & 0.4 & 41 & 0 & 0 \\
Total & $\mathbf{2 5 9}$ & $\mathbf{1}$ & $\mathbf{0 . 4}$ & $\mathbf{7 8 7}$ & $\mathbf{4}$ & $\mathbf{0 . 5}$ & $\mathbf{9 7}$ & $\mathbf{0}$ & $\mathbf{0}$ \\
\hline
\end{tabular}

nt $=$ not tested 
The isolation test on mice to demonstrate $T$. gondii in tissues was completed in 97 pigs (56 and 41 from the second and third samplings, respectively). No T. gondii tissue cysts were found in the brains of experimental mice (Tab. 1). The results of IFAT in these mice were negative, too.

\section{Discussion}

The number of papers published recently on toxoplasmosis only serves to emphasize the importance attributed to the problem. The 1990s witnessed an increased attention to toxoplasmosis both in the USA (Dubey 1995; Kliebenstein 1997; Davies 1998, Gamble 1999) and in Canada (Smith 1991; Gajadhar 1998). In Europe, results of serological tests on pigs have been published in Italy where the seroprevalence was $64.4 \%$ (Genchi 1991), in the Netherlands where the seroprevalence among fattened pigs and breeding sows was $1.8 \%$ and $30.9 \%$, respectively (van Knapen 1995). In the neighbouring Austria, seroprevalence against $T$. gondii in pigs was only $0.9 \%$ (Edelhofer 1992).

A low seroprevalence in slaughter pigs has been reported in a number of papers: $0.9 \%$ (Edelhofer 1992), 2.2\% (Dubey 1995), 1.8\% (van Knapen 1995), 0.58\% (Davies 1998). The main reasons for the low (or decreasing) seroprevalence are believed to be an improved zoohygienic situation on farms, good sanitation and the exclusive use of commercially marketed feeds. Pigs with a low seroprevalence were reared in facilities that did not allow entry to cats. In the 1981-1990 and 1999, we monitored the Kladruby farm and found only low seroprevalence and parasitological prevalence: from 1981 to 1990, seropositivity levels of the Kladruby pigs in the CFT and SFT tests were $0 \%(n=512)$ and $3.6 \%(\mathrm{n}=1023)$, respectively. The result of the $T$. gondii isolation assay of porcine tissues

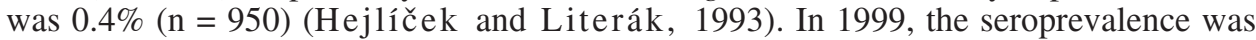
$0.5 \%(\mathrm{n}=787)$ and $0.4 \%(\mathrm{n}=259)$ in the CFT and SFT tests, respectively, and no T. gondii was isolated from porcine tissues. The difference between toxoplasmosis prevalence figures from the 1981-1990 and the 1999 is not significant (Tab. 2). During observed period there were no significant changes in the technology of raising and no specific arrangements against toxoplasmosis were done. The farm was a large-scale pig-rearing facility with very good zoohygienic and sanitation parameters, and constant veterinary supervision. Only commercially marketed feeds were used on the farm, and no cats were allowed in the halls. Although the farm does not breed its own piglets, they are purchased from only 8 selected suppliers who must meet the farm's strict criteria, including excellent zoohygienic and sanitation, and an absence of health problems in piglets or sows. The reasons for a low pig toxoplasmosis prevalence on the farm studied by the authors were good conditions of pig rearing.

Table 2

Comparison of the results of examination pigs for toxoplasmosis in 1981-1990 and 1999

\begin{tabular}{|l|c|c|c|c|c|c|c|c|c|}
\hline \multirow{2}{*}{ Examination date } & \multicolumn{3}{|c|}{ SFT } & \multicolumn{3}{c|}{ CFT } & \multicolumn{3}{c|}{ Isolation experiment } \\
\cline { 2 - 11 } & No. & Pos. & $\%$ Pos. & No. & Pos. & $\%$ Pos. & No. & Pos. & $\%$ Pos. \\
\hline $\begin{array}{l}\text { 1981-1990 } \\
\text { (Hejlíček and Literák, 1993) }\end{array}$ & 1023 & 37 & 3.6 & 512 & 0 & 0 & 950 & 4 & 0.4 \\
\hline $\begin{array}{l}1999 \\
\text { (present study) }\end{array}$ & 259 & 1 & 0.4 & 787 & 4 & 0.5 & 97 & 0 & 0 \\
\hline
\end{tabular}

By the comparison of the T. gondii prevalence on a large-scale pig-rearing farm in 1999 with that in the 1981-1990 period, the prevalence of pig toxoplasmosis on the Kladruby farm did not increase. 


\section{Prevalence Toxoplasma gondii u výkrmových prasat na velkokapacitní farmě v České republice}

V roce 1999 (leden, duben, listopad) byla vyšetřována jatečná prasata z moderního velkochovu v jižních Čechách na protilátky proti Toxoplasma gondii a průkaz T. gondii. V KFR (komplementfixační reakce) byly zjištěny protilátky u $4(0,5 \%)$ prasat ze 787 . Za pozitivní byl považován titr 8 . V SFR (Sabin-Feldmanova reakce) bylo vyšetřeno 259 jatečných prasat a protilátky byly zjištěny u $1(0,4 \%)$ prasete. Za pozitivní byl považován titr 4. Izolačním biologickým pokusem na laboratorních myších byly vyšetřeny vzorky tkání mozku a svaloviny bráničného pilîře z celkem 97 náhodně vybraných prasat $\mathrm{z}$ dubnového a listopadového odběru. Výsledek izolačního biologického pokusu byl negativní. Z výsledků vyplynulo, že při porovnávání prevalence toxoplazmózy zjištěné v roce 1999 s obdobím 1981-1990 nedošlo ve sledovaném moderním velkochovu prasat s vysokou úrovní zoohygieny a veterinárního dozoru $\mathrm{k}$ žádným významným změnám v prevalenci toxoplazmózy.

\section{Acknowledgement}

This study was supported by the Research Project 161700001 of the Ministry of Education, Youth and Sports of the Czech republic and Project 524/98/0111 of the Grant Agency of the Czech Republic. The authors gratefully acknowledge the assistance of Mrs. Tomášková and Dr. Kodym from the National Reference Laboratory for Toxoplasmosis (National Health Institute, Prague), who performed confirmation tests of positive serum samples.

\section{References}

DAVIES, P. R., MORROW, W. E. M., DEEN, J., GAMBLE, H. R., PATTON, S. 1998: Seroprevalence of Toxoplasma gondii and Trichinella spiralis in finishing swine raised in different production systems in North Carolina, USA. Preventive Veterinary Medicine 36: 67-76

DUBEY, J. P., BEATTIE, C. P. 1988: Toxoplasmosis of Animals and Man. CRC Press, Inc. Boca Raton, Florida: 1-220 (toxoplasmosis in pigs p. 91-106)

DUBEY, J. P., WEIGEL, R. M., Siegel, A. M. et al. 1995: Sources and reservoirs of Toxoplasma gondii infection on 47 swine farms in Illinois. J. Parasitol. 81: 723-729

EDELHOFER, R. 1994: Prevalence of antibodies against Toxoplasma gondii in pigs in Austria - an evaluation of data from 1982 and 1992. Parasitol. Res. 80: 642-644

GAJADHAR, A. A., ARAMINI, J. J., TIFFIN, G., BISAILLON, J. R. 1998: Prevalence of Toxoplasma gondii in Canadian market-age pigs. J. Parasitol. 84: 759-763

GAMBLE, H. R., BRADY, R. C., DUBEY, J. P. 1999: Prevalence of Toxoplasma gondii infection in domestic pigs in the New England states. Vet. Parasitol. 82: 129-136

GENCHI, G., POLIDORI, G. A., ZAGHINI, L., LANFRANCHI, P. 1991: Epidemiological aspects of toxoplasmosis on intensive pig farms. Archivio Veterinario Italiano 42: 105-111

HEJLÍ́CEK, K., LITERÁK, I. 1993: Prevalence of toxoplasmosis in pigs in the region of South Bohemia. Acta Vet. Brno 62: 159-166

JÍRA, J., ROSICKÝ, B. 1983: Imunodiagnostika a epidemiologie toxoplasmosy. Academia Praha, pp. 11-262

KLIEBENSTEIN, J., PATTON, S., ZIMMERMAN, J. et al. 1997: Toxoplasma gondii in United States swine operations: an assessment of management factors. Epidémiol. santé anim. 31 - 32: 05.26.1 - 05.26.3

VAN KNAPEN, F., KREMERS, A. F., FRANCHIMONT, J. H., NARUCKA, U. 1995: Prevalence of antibodies to Toxoplasma gondii in cattle and swine in The Netherlands: towards an integrated control of livestock production. Vet. Q. 17: 87-91

KOUBA, K., JÍRA, J., HÜBNER, J. 1974: Toxoplazmóza. Avicenum, Praha: 5-306

SMITH, H. J. 1991: Seroprevalence of anti - Toxoplasma IgG in Canadian swine. Can. J. Vet. Res. 55: 380-381

WEIGEL, R. M., DUBEY, J. P., SIEGEL, A. M., HOEFLING, D. et al. 1995: Prevalence of antibodies to Toxoplasma gondii in swine in Illinois in 1992. J. Am. Vet. Med. Assoc. 206: 1747-51 